\title{
Molecular Dermatopathology in Malignant Melanoma
}

\author{
Marie-Annick Reginster, Claudine Pierard-Franchimont, \\ Gérald E. Piérard, and Pascale Quatresooz \\ Department of Dermatopathology, University Hospital Sart Tilman, 4000 Liège, Belgium \\ Correspondence should be addressed to Gérald E. Piérard, gerald.pierard@ulg.ac.be
}

Received 30 June 2011; Accepted 19 August 2011

Academic Editor: Philippe Humbert

Copyright (C 2012 Marie-Annick Reginster et al. This is an open access article distributed under the Creative Commons Attribution License, which permits unrestricted use, distribution, and reproduction in any medium, provided the original work is properly cited.

\begin{abstract}
At present, immunohistochemistry is taken for granted in the establishment of malignant melanoma (MM) diagnosis. In recent years, molecular diagnosis in dermatopathology has benefited from a vast array of advances in the fields of genomics and proteomics. Sensitive techniques are available for detecting specific DNA and RNA sequences by molecular hybridization. This paper intends to update methods of molecular cytogenetics available as diagnostic adjuncts in the field of MM. Cytogenetics has highlighted the pathogenesis of atypical melanocytic neoplasms with emphasis on the activation of the mitogen-activated protein kinase (MAPK) signalling pathway during the initiation step of the neoplasms. 20 to 40\% of MM families have mutations in the tumour suppressor gene p16 or CDKN2A. In addition, somatic mutations in p16, p53, BRAF, and cKIT are present in MM. Genome-wide scan analyses on MM indicate positive associations for genes involved in melanocytic naevi, but MM is likely caused by a variety of common low-penetrance genes. Molecular dermatopathology is expanding, and its use in the assessment of melanocytic neoplasms appears to be promising in the fields of research and diagnosis. Molecular dermatopathology will probably make its way to an increased number of diagnostic laboratories. The expected benefit should improve the patient management. This evolution points to a need for evolution in the training requirements and role of dermatopathologists.
\end{abstract}

\section{Introduction}

In some instances, identifying cutaneous malignant melanoma (MM) in routine histopathology may prove to be a challenging exercise [1-3]. The diagnostic process is hampered by a series of clinical and histopathological limitations in both the definition of objective criteria and establishment of undisputable diagnostic consensus. Over the past decades, the development of immunopathology notably shifted the diagnostic procedure from descriptive morphology to molecular histopathology [4-8]. Immunopathology helps distinguishing some atypical melanocytic neoplasms and supports refined MM staging [9-18]. In recent years, other progresses were made beyond regular microscopy in the fields of molecular biology and molecular morphology for the detection of pathogenic mutations expressed in DNA, RNA, and proteins. Such sensitive procedures applied to MM help in the diagnosis, classification, and outcome prediction, as well as in selecting and monitoring therapy [19-24]. Of note, mutations altering a protein due to amino acid substitution have to be distinguished from mutations occurring in a given amino acid and corresponding to silent mutations or polymorphism.

The aim of this paper was to revisit recent insights in molecular dermatopathology shedding some light on the pathogenesis and diagnosis of MM. The accent will be on molecular cytogenetics referring to the molecular structure and the function of chromosomes. The covered techniques are currently used for research or diagnostic purposes.

\section{Complementary Sampling Methods}

Two special sampling methods are particularly suited for some methods used in molecular dermatopathology.

Laser cutting dissection helps isolating circumscribed cell populations under the microscope in an attempt at increasing homogeneity of isolates based on morphological criteria $[25,26]$.

Tissue microarrays correspond to an ordered set of minute tissue cores (roughly $0.6 \mathrm{~mm}$ in diameter) obtained 
from a variety of specimens and embedded in a single paraffin block. For comparative purposes, immunohistochemistry and a range of downstream molecular methods are conveniently applied to tissue microarrays $[18,27]$. For instance, tissue microarrays from different MM samples at different stages of progression were used to disclose distinct molecular alterations [27]. In this field, immunohistochemistry on tissue microarrays has identified osteopontin expression as the first feature acquired during the initial step of $\mathrm{MM}$ invasion [27].

\section{Molecular Morphology and Biology at a Glance}

3.1. In Situ Hybridization. In situ hybridization (ISH) provides morphological demonstration of specific DNA and RNA sequences in tissue sections, single cells, or chromosome spreads. ISH relies on labelled single- or doublestrand DNA or RNA sequences containing complementary sequences that hybridize to cellular DNA or RNA under appropriate conditions to form stable hybrids. The optimal probe length for ISH results in maximized tissue penetration and high hybridization rate. It averages $50-300$ bases.

Primed in situ (PRINS) labelling relies on a primermediated DNA synthesis carried out in situ on tissue sections. The technique starts with annealing an oligonucleotide DNA primer adjacent to the DNA region of interest. This molecular structure serves as a primer for the Tag polymerase incorporating the four nucleotides dATP, dGTP, dCTP, and the labelled dUTP which is conveniently revealed using immunohistochemistry. These ISH and PRINS methods are used for localizing DNA sequences and specific mRNA in cells and tissues, as well as visualizing chromosomes allowing interphase cytogenetics and detection of specific mRNA. Thus, HIS and PRINS methods were developed using chromosome-specific probes or oligonucleotides for the detection of numerical and structural chromosome aberrations in interphase nuclei in both fresh and formalin-fixed tissue sections.

3.2. Chromosomal G Banding Method. Chromosomal G banding (CGB) detects gross aberrations in chromosomes under microscopic examination $[18,28]$. Cell cultures from fresh MM sampling are followed by stabilization of mitotic figures in metaphase. Enzyme digestion followed by histochemical staining reveals CGB. Of note, subtle chromosomal aberrations including point mutations, small insertions, and deletions, as well as discrete rearrangements are not disclosed using the CGB method [24].

3.3. FISH Method. Fluorescence in situ hybridization (FISH) relies on hybridization of fluorescent complementary DNA probes recognizing specific genes or DNA oligonucleotides [29]. The method is performed on fresh or formalin-fixed tissue sections, as well as on nuclei spreads and DNA microarrays. The number of spots per nucleus is indicative of the copy number of the scrutinized chromosome locus. Sequences of the whole genome, centromeres, telomeres, and specific gene regions are conveniently used as probes.
A translocation is detected by a spot splitting into two parts, or by different fluorescent probes that hybridize on each of the translocated genes.

FISH helps identifying mutated cells including those in the apparently normal skin at distance from the MM [30]. Recent FISH variants were developed in various ways [24, 31]. FISH allows detecting subtle chromosome aberrations in MM including four targeted genes, namely, CEP6, RREB1, MYB and CCND1 [32-35].

One pitfall of the FISH method results from the partial entrapping of the nuclei volume in the tissue sections causing technical omission of chromosome segments. Hence, a number of nuclei must be scrutinized for ensuring a reliable assessment of the copy number of the probe [36].

3.4. CGH Method. Comparative genomic hybridization (CGH) compares DNA from a melanocytic neoplasm to DNA from a normal reference tissue of the same patient. The CGH method is conveniently performed using fresh or formalin-fixed tissue. The DNA labelled with different fluorochromes is subsequently hybridized on normal metaphase chromosomes or on arrays of small spots of DNA [24]. Data are expressed as a gain or loss of copy number [37]. CGH has identified some genome aberrations and imbalance in MM [38], but only when genome aberrations are enough represented in neoplastic cells [31]. CGH is mainly used in research settings $[38,39]$ where it helps identifying genomic signatures distinguishing different MM types [40-42]. Of note, Spitz naevi (melanocytomas) [43] contain genetic aberrations corresponding to single $11 \mathrm{p}$ gains $[19,38]$. MM arising in congenital melanocytic naevi shows CGH patterns comparable to regular MM, while atypical nodules (melanocytomas) contain numerical aberrations of entire chromosomes, which are seen only in a minority of MM [44].

3.5. Gene Microarray Method. Gene microarrays also named DNA chips allow scrutinizing RNA and microRNA (miRNA) expression, as well as detecting DNA mutations and polymorphism [45-47]. The method is applicable to fresh or formalin-fixed tissue [47]. The procedure involves immobilization of specific DNA sequences on a solid platform, to which complementary labelled DNA hybridizes. The labelled DNA is obtained from reverse transcription of mRNA extracted from the test tissue. The immobilized DNA corresponds to either oligonucleotides or complementary DNA [24]. Following the hybridization process, the labelled spots are scrutinized. The complexity of the multiple data requires adequate statistical analysis and computerized mathematical models.

Gene microarray signatures were offered for molecular classification of MM and naevi in diagnostic dermatopathology [47]. In such screening, 36 different gene signatures were found between melanocytic naevi and MM.

3.6. PCR and RTP-CR Methods. The PCR (polymerase chain reaction) substrate corresponds to DNA or RNA (reverse transcriptase, RT-PCR), extracted from fresh or formalinfixed tissue. The method corresponds to a chemical reaction 
driven by cyclic changes in temperature leading to a specific and exponential amplification of small fragments of the target DNA or RNA over a short period of time. PCR was applied to the identification of MM micrometastases [48] using selected markers including me20m, PLAB, SPP1, CAPG, and CTSB $[24,26,49]$.

While immunohistochemistry improves the sensitivity of metastasis detection by $10-45 \%$ compared with regular histopathology, RT-PCR for MM-related marker gene expression, like tyrosinase and Melan A-Mart-1, was reported to increase the detection of suspected occult metastases up to $70 \%$ [24]. Indeed, RT-PCR is expected to detect one MM cell out of $10^{6}-10^{7}$ non-MM cells, while immunohistochemistry probably detects one MM cell in about $10^{4}$ $10^{5}$ non-MM cells [21]. The relevance of PCR detection of MM micrometastases in lymph nodes was, however, challenged because of the apparent lack of prognostic value of the findings [50]. Indeed, in addition to the identification of MM micrometastasis within sentinel lymph nodes, the size and location of the metastasis should be assessed [51]. Thus, the role of nonmicroscopic methods to investigate the sentinel lymph node remains doubtful. In such procedure, a histopathological assessment of the location, size, and nature of the suspected MM cells is lacking and misinterpretation of nodal nevus cells as metastasis may occur. This drawback might be overcome by using highly specific methods detecting only MM cells [52], but the size and location of the micrometastases remain unassessed.

In situ PCR-based amplification of the target nucleic acid sequences may be performed before performing ISH. In situ PCR is performed on cells or tissues are fixed and permeabilized respecting the morphology and allowing access of the PCR probes to the intranuclear sequences that have to be amplified. Cell suspensions or tissue sections are overlaid with PCR reagents, sealed off with a coverslip, and submitted to thermal cycling. The PCR products are detected using PCR probes (indirect in situ PCR) or through direct detection of labelled nucleotides incorporated into PCR products (direct in situ PCR).

3.7. MLPA Method. Multiplex ligation-dependent probe amplification (MLPA) is based on annealing up to 45 probes each consisting of two oligonucleotides that hybridize next to each other on a specific chromosome region [53]. In addition to target-specific sites, both oligonucleotides, contain a universal PCR primer. In addition, one oligonucleotide contains a so-called stuffer sequence showing a probe-specific length. After ligation of the hybridized adjacent oligonucleotides the probe is amplified using PCR primers. As each probe has a unique length due to the stuffer sequence, electrophoresis conveniently separates and quantifies the amount of PCR product indicating the DNA copy number [24]. Mutationspecific MLPA combines copy number detection and hotspot mutations in a single assessment [54].

3.8. HRMA Method. High-resolution melting analysis (HRMA) is based on the DNA dissociation after heating at high resolution. This procedure allows for the detection of single-base pair sequence variations [55]. This rapid method detects hot-spot mutations and possibly identifies mutated cells when present in at least $5 \%$ of a background of cells showing wild-type DNA [56].

\section{Germline and Somatic MM Mutations}

Multiple naevi associated with increased MM risk predominantly occur in families with p16 or CDKN2A mutations [57]. However, searching for p16 or CDKN2A mutations is not clinically relevant in other MM patients as the probability of detecting a mutation is small [58]. The prevalence of familial p16 mutations is related to the number of MMs in relatives [57]. More than 30 different p16 mutations have been reported so far [58]. Globally, p16 mutations are present in $25-40 \%$ of MM families with more than $2 \mathrm{MMs}$, while the proportion of p16 mutations is lower in families with 2 MMs only [59]. In addition, individuals with multiple primary MM are more likely to have p16 mutations [60].

The p16 gene produces two different polypeptides, namely, the p16/INK4a and the p14/ARF proteins. Both of them participate in the control of the cell cycle of proliferation. According to the exon mutation, the p16 and/or p14 functions are altered. Indeed, most MMs are unrelated to germline p16 mutations especially in the nonfamilial MM. Many other common MM genes of lower penetrance are probably involved in MM. These mutations increase with the progression of the disease [61]. Multiple dysplastic naevi are a marker of MM risk and susceptibility to other cancers as well [62]. MM is therefore likely to share cancer genes with other neoplasms because $\mathrm{MM}$ is common in the family cancer syndromes. Individuals with BRCA2 and BRCA1 mutations have an increased risk of $\mathrm{MM}$ on the skin and eyes [63].

Genetic aberrations in cutaneous MM correlate with specific phenotypes [64]. Of note, the progression from a melanocyte to a MM cell is supported by a series of morphological changes, and a series of currently unravelled genetic aberrations. Both the mitogen-activated protein kinase (MAPK) signalling pathway and the PTEN/AKT pathway are involved in the growth control of melanocytes [65]. Activation of these pathways following somatic mutations in the RAS and RAF genes might represent one of the initial steps in the development of melanocytic naevi [66]. The BRAF oncogene on chromosome $7 \mathrm{Q} 34$ is commonly mutated in over $70 \%$ of MMs [67], but this mutation is absent in giant congenital melanocytic naevi [68]. MM with multiple naevi and BRAF mutation occur more frequently at a younger age and on intermittently sun-exposed sites [69]. By contrast, p53 mutations are more common in lentigo maligna or MM developed on chronically sun-exposed sites of older patients showing prominent actinic damage [70]. Distinct somatic gene mutations such as at the cKIT locus were identified in other MMs, particularly on the mucosa, palms, and soles [71], and in hyperpigmented MM [15]. Genes potentially involved in MM metastases include those involved in the MAPK pathway, such as BRAF and RAS. New MM therapies targeting the BRAF and cKIT pathways call for genotyping $\mathrm{MM}$ in order to select the proper patients [71-76]. 
Blue naevi, Spitz melanocytomas, congenital melanocytic naevi, and uveal MM do not or rarely contain BRAF mutations [68]. By contrast, they contain other mutations such as in the NRAS or HRAS genes [77]. In addition, somatic mutations of GNAQ in the RAS-like domain were found in both uveal MM and blue naevi [78]. Similarly to BRAF mutations, the RAS and GNAQ mutations may cause MAPK activation and form an alternative route for melanocytic neoplasia [55]. Even if all these mutations seem to represent early events in the development of melanocytic neoplasms, they do not cause melanocytic progression towards MM.

\section{Conclusion}

Most of the molecular methods available in dermatopathology currently remain research-based approaches. In such setting, molecular diagnosis appears increasingly important for predicting the biological behaviour of MM. New markers correlating with poor prognosis have been reported. It appears that MM is a genetically heterogeneous neoplasm with different risk phenotypes and genotypes.

\section{Conflict of Interests}

The authors have declared no conflict of interests.

\section{Acknowledgments}

This work was supported by a grant from the "Fonds d'Investissement de la Recherche Scientifique" of the University Hospital of Liège. No other sources of funding were used to assist in the preparation of this paper. The authors appreciate the excellent secretarial assistance of Mrs. Ida Leclercq.

\section{References}

[1] L. Brochez, E. Verhaeghe, E. Grosshans et al., "Inter-observer variation in the histopathological diagnosis of clinically suspicious pigmented skin lesions," Journal of Pathology, vol. 196, no. 4, pp. 459-466, 2002.

[2] O. E. Dadzie, J. Goerig, and J. Bhawan, "Incidental microscopic foci of nevic aggregates in skin," The American Journal of Dermatopathology, vol. 30, no. 1, pp. 45-50, 2008.

[3] S. Lodha, S. Saggar, J. T. Celebi, and D. N. Silvers, "Discordance in the histopathologic diagnosis of difficult melanocytic neoplasms in the clinical setting," Journal of Cutaneous Pathology, vol. 35, no. 4, pp. 349-352, 2008.

[4] M. R. Nasr and O. El-Zammar, "Comparison of pHH3, Ki67 , and survivin immunoreactivity in benign and malignant melanocytic lesions," The American Journal of Dermatopathology, vol. 30, no. 2, pp. 117-122, 2008.

[5] S. J. Ohsie, G. P. Sarantopoulos, A. J. Cochran, and S. W. Binder, "Immunohistochemical characteristics of melanoma," Journal of Cutaneous Pathology, vol. 35, no. 5, pp. 433-444, 2008.

[6] A. G. Abdou, M. A. Hammam, S. E. El-Farargy et al., "Diagnostic and prognostic role of galectin 3 expression in cutaneous melanoma," The American Journal of Dermatopathology, vol. 32, no. 8, pp. 809-814, 2010.
[7] P. Quatresooz, C. Piérard-Franchimont, P. Paquet, and G. E. Piérard, "Angiogenic fast-growing melanomas and their micrometastases," European Journal of Dermatology, vol. 20, no. 3, pp. 302-307, 2010.

[8] P. Quatresooz, M. A. Reginster, and G. E. Piérard, "The "malignant melanoma microecosystem". Immunohistopathological insights into the stromal cell phenotype. A review," Experimental and Therapeutic Medicine, vol. 2, no. 3, pp. 379-384, 2011.

[9] S. R. Alonso, P. Ortiz, M. Pollán et al., "Progression in cutaneous malignant melanoma is associated with distinct expression profiles. A tissue microarray-based study," The American Journal of Pathology, vol. 164, no. 1, pp. 193-203, 2004.

[10] N. Claessens, G. E. Piérard, C. Piérard-Franchimont, J. E. Arrese, and P. Quatresooz, "Immunohistochemical detection of incipient melanoma micrometastases. Relationship with sentinel lymph node involvement," Melanoma Research, vol. 15, no. 2, pp. 107-110, 2005.

[11] L. A. Fecher, S. D. Cummings, M. J. Keefe, and R. M. Alani, "Toward a molecular classification of melanoma," Journal of Clinical Oncology, vol. 25, no. 12, pp. 1606-1620, 2007.

[12] P. Quatresooz, G. E. Piérard, C. Piérard-Franchimont, and the Mosan Study Group of Pigmented Tumors, "Molecular pathways supporting the proliferation staging of malignant melanoma," International Journal of Molecular Medicine, vol. 24, no. 3, pp. 295-301, 2009.

[13] P. Quatresooz, C. Piérard-Franchimont, G. E. Piérard, and the Mosan Study Group of Pigmented Tumors, "Molecular histology on the diagnostic cutting edge between malignant melanomas and cutaneous melanocytomas," Oncology Reports, vol. 22, no. 6, pp. 1263-1267, 2009.

[14] D. Vitoux, S. Mourah, D. Kerob et al., "Highly sensitive multivariable assay detection of melanocytic differentiation antigens and angiogenesis biomarkers in sentinel lymph nodes with melanoma micrometastases," Archives of Dermatology, vol. 145, no. 10, pp. 1105-1113, 2009.

[15] J. M. Wu, H. Alvarez, P. García et al., "Melanoma hyperpigmentation is strongly associated with KIT alterations," The American Journal of Dermatopathology, vol. 31, no. 7, pp. 619625, 2009.

[16] B. N. Bernaba, P. I. Vogiatzis, S. W. Binder, and D. S. Cassarino, "Potentially useful markers for desmoplastic melanoma: an analysis of KBA.62, p-AKT, and ezrin," The American Journal of Dermatopathology, vol. 33, no. 4, pp. 333-340, 2011.

[17] P. S. Nielsen, R. Riber-Hansen, and T. Steiniche, "Immunohistochemical double stains against Ki67/MART1 and HMB45/ MITF: promising diagnostic tools in melanocytic lesions," The American Journal of Dermatopathology, vol. 33, no. 4, pp. 361370, 2011.

[18] P. Quatresooz and G. E. Piérard, "Malignant melanoma: from cell kinetics to micrometastases," The American Journal of Clinical Dermatology, vol. 12, no. 2, pp. 77-86, 2011.

[19] J. A. Carlson, J. S. Ross, A. Slominski et al., "Molecular diagnostics in melanoma," Journal of the American Academy of Dermatology, vol. 52, no. 5, pp. 743-775, 2005.

[20] K. K. Sra, M. Babb-Tarbox, S. Aboutalebi et al., "Molecular diagnosis of cutaneous diseases," Archives of Dermatology, vol. 141, no. 2, pp. 225-241, 2005.

[21] J. A. Carlson, J. S. Ross, and A. J. Slominski, "New techniques in dermatopathology that help to diagnose and prognosticate melanoma," Clinics in Dermatology, vol. 27, no. 1, pp. 75-102, 2009.

[22] R. Lazova, B. E. Rothberg, D. Rimm, and G. Scott, "The semaphorin 7A receptor plexin $\mathrm{C} 1$ Is lost during melanoma 
metastasis," The American Journal of Dermatopathology, vol. 31, no. 2, pp. 177-181, 2009.

[23] W. A. M. Blokx, M. C. van Dijk, and D. J. Ruiter, "Molecular cytogenetics of cutaneous melanocytic lesions-diagnostic, prognostic and therapeutic aspects," Histopathology, vol. 56, no. 1, pp. 121-132, 2010.

[24] O. E. Dadzie, M. Neat, A. Emley, J. Bhawan, and M. Mahalingam, "Molecular diagnostics. An emerging frontier in dermatopathology," The American Journal of Dermatopathology, vol. 33, pp. 1-16, 2011.

[25] O. E. Dadzie, S. Yang, A. Emley, M. Keady, J. Bhawan, and M. Mahalingam, "RAS and RAF mutations in banal melanocytic aggregates contiguous with primary cutaneous melanoma: clues to melanomagenesis," The British Journal of Dermatology, vol. 160, no. 2, pp. 368-375, 2009.

[26] P. Uribe, I. I. Wistuba, and S. Gonzalez, "Allelotyping, microsatellite instability, and braf mutation analyses in common and atypical melanocytic nevi and primary cutaneous melanomas," The American Journal of Dermatopathology, vol. 31, no. 4, pp. 354-363, 2009.

[27] Y. Zhou, D. L. Dai, M. Martinka et al., "Osteopontin expression correlates with melanoma invasion," Journal of Investigative Dermatology, vol. 124, no. 5, pp. 1044-1052, 2005.

[28] M. A. Carless and L. R. Griffiths, "Cytogenetics of melanoma and nonmelanoma skin cancer," Advances in Experimental Medicine and Biology, vol. 624, pp. 227-240, 2008.

[29] S. Gellrich, R. Ventura, M. Jones, S. Y. Tan, and D. Y. Mason, "Immunofluorescent and FISH analysis of skin biopsies," The American Journal of Dermatopathology, vol. 26, no. 3, pp. 242247, 2004.

[30] B. C. Bastian, M. Kashani-Sabet, H. Hamm et al., "Gene amplifications characterize acral melanoma and permit the detection of occult tumor cells in the surrounding skin," Cancer Research, vol. 60, no. 7, pp. 1968-1973, 2000.

[31] M. Braun-falco, W. Schempp, and W. Weyers, "Molecular diagnosis in dermatopathology: what makes sense, and what doesn't," Experimental Dermatology, vol. 18, no. 1, pp. 12-23, 2009.

[32] P. Gerami, S. S. Jewell, L. E. Morrison et al., "Fluorescence in situ hybridization (FISH) as an ancillary diagnostic tool in the diagnosis of melanoma," The American Journal of Surgical Pathology, vol. 33, no. 8, pp. 1146-1156, 2009.

[33] A. L. Morey, R. Murali, S. W. McCarthy, G. J. Mann, and R. A. Scolyer, "Diagnosis of cutaneous melanocytic tumours by four-colour fluorescence in situ hybridisation," Pathology, vol. 41, no. 4, pp. 383-387, 2009.

[34] M. D. Newman, T. Lertsburapa, M. Mirzabeigi, M. Mafee, J. Guitart, and P. Gerami, "Fluorescence in situ hybridization as a tool for microstaging in malignant melanoma," Modern Pathology, vol. 22, no. 8, pp. 989-995, 2009.

[35] M. D. Newman, M. Mirzabeigi, and P. Gerami, "Chromosomal copy number changes supporting the classification of lentiginous junctional melanoma of the elderly as a subtype of melanoma," Modern Pathology, vol. 22, no. 9, pp. 1258-1262, 2009.

[36] J. D. Lee, E. R. Unger, C. Gittenger, D. R. Lee, R. Hebert, and J. C. Maize, "Interphase cytogenetic analysis of 1q12 satellite III DNA in melanocytic lesions: increased aneuploidy with malignant histology," The American Journal of Dermatopathology, vol. 23, no. 3, pp. 176-180, 2001.

[37] J. W. M. Jeuken, S. H. E. Sprenger, and P. Wesseling, "Comparative genomic hybridization: practical guidelines," Diagnostic Molecular Pathology, vol. 11, no. 4, pp. 193-203, 2002.
[38] B. C. Bastian, A. B. Olshen, P. E. LeBoit, and D. Pinkel, "Classifying melanocytic tumors based on DNA copy number changes," The American Journal of Pathology, vol. 163, no. 5, pp. 1765-1770, 2003.

[39] J. Bauer and B. C. Bastian, "Distinguishing melanocytic nevi from melanoma by DNA copy number changes: comparative genomic hybridization as a research and diagnostic tool," Dermatologic Therapy, vol. 19, no. 1, pp. 40-49, 2006.

[40] B. C. Bastian, A. B. Olshen, P. E. LeBoit, and D. Pinkel, "Classifying melanocytic tumours based on DNA copy number changes," The American Journal of Pathology, vol. 163, no. 5, pp. 1765-1770, 2003.

[41] P. D. Da Forno, A. Fletcher, J. H. Pringle, and G. S. Saldanha, "Understanding spitzoid tumours: new insights from molecular pathology," The British Journal of Dermatology, vol. 158, no. 1, pp. 4-14, 2008.

[42] M. J. Murphy, M. Jen, M. W. Chang, J. M. Grant-Kels, and H. Makkar, "Molecular diagnosis of a benign proliferative nodule developing in a congenital melanocytic nevus in a 3-monthold infant," Journal of the American Academy of Dermatology, vol. 59, no. 3, pp. 518-523, 2008.

[43] P. Quatresooz, C. Piérard-Franchimont, and G. E. Piérard, "Highlighting the immunohistochemical profile of melanocytomas," Oncology Reports, vol. 19, no. 6, pp. 1367-1372, 2008.

[44] B. C. Bastian, J. Xiong, I. J. Frieden et al., "Genetic changes in neoplasms arising in congenital melanocytic nevi: differences between nodular proliferations and melanomas," The American Journal of Pathology, vol. 161, no. 4, pp. 1163-1169, 2002.

[45] M. Kunz, S. M. Ibrahim, D. Koczan, S. Scheid, H. J. Thiesen, and G. Gross, "DNA microarray technology and its applications in dermatology," Experimental Dermatology, vol. 13, no. 10, pp. 593-606, 2004.

[46] K. Sellheyer and T. J. Belbin, "DNA microarrays: from structural genomics to functional genomics. The applications of gene chips in dermatology and dermatopathology," Journal of the American Academy of Dermatology, vol. 51, no. 5, pp. 681692, 2004.

[47] S. S. Koh, M. L. Opel, J. P. J. Wei et al., "Molecular classification of melanomas and nevi using gene expression microarray signatures and formalin-fixed and paraffin-embedded tissue," Modern Pathology, vol. 22, no. 4, pp. 538-546, 2009.

[48] H. Takeuchi, D. L. Morton, C. Kuo et al., "Prognostic significance of molecular upstaging of paraffin-embedded sentinel lymph nodes in melanoma patients," Journal of Clinical Oncology, vol. 22, no. 13, pp. 2671-2680, 2004.

[49] B. Boone, M. V. Gele, J. Lambert, M. Haspeslagh, and L. Brochez, "The role of RhoC in growth and metastatic capacity of melanoma," Journal of Cutaneous Pathology, vol. 36, no. 6, pp. 629-636, 2009.

[50] C. Tatlidil, W. S. Parkhill, C. A. Giacomantonio, W. L. Greer, S. F. Morris, and N. M. G. Walsh, "Detection of tyrosinase mRNA in the sentinel lymph nodes of melanoma patients is not a predictor of short-term disease recurrence," Modern Pathology, vol. 20, no. 4, pp. 427-434, 2007.

[51] R. A. Scolyer, R. Murali, S. W. McCarthy, and J. F. Thompson, "Pathologic examination of sentinel lymph nodes from melanoma patients," Seminars in Diagnostic Pathology, vol. 25, no. 2, pp. 100-111, 2008.

[52] M. G. Cook and S. Di Palma, "Pathology of sentinel lymph nodes for melanoma," Journal of Clinical Pathology, vol. 61, no. 8, pp. 897-902, 2008.

[53] M. C. van Dijk, P. D. Rombout, S. H. Boots-Sprenger et al., "Multiplex ligation-dependent probe amplification for the detection of chromosomal gains and losses in formalin-fixed 
tissue," Diagnostic Molecular Pathology, vol. 14, no. 1, pp. 916, 2005.

[54] J. Rangel, M. Nosrati, S. P. L. Leong et al., "Novel role for RGS1 in melanoma progression," The American Journal of Surgical Pathology, vol. 32, no. 8, pp. 1207-1212, 2008.

[55] M. Erali, K. V. Voelkerding, and C. T. Wittwer, "High resolution melting applications for clinical laboratory medicine," Experimental and Molecular Pathology, vol. 85, no. 1, pp. 5058, 2008.

[56] D. J. Bunyan, A. C. Skinner, E. J. Ashton et al., "Simultaneous MLPA-based multiplex point mutation and deletion analysis of the dystrophin gene," Molecular Biotechnology, vol. 35, no. 2, pp. 135-140, 2007.

[57] D. T. Bishop, F. Demenais, A. M. Goldstein et al., "Geographical variation in the penetrance of CDKN2A mutations for melanoma," Journal of the National Cancer Institute, vol. 94, no. 12, pp. 894-903, 2002.

[58] J. A. Newton Bishop and N. A. Gruis, "Genetics: what advice for patients who present with a family history of melanoma?" Seminars in Oncology, vol. 34, no. 6, pp. 452-459, 2007.

[59] A. M. Goldstein, M. Chan, M. Harland et al., "Features associated with germline CDKN2A mutations: a GenoMEL study of melanoma-prone families from three continents," Journal of Medical Genetics, vol. 44, no. 2, pp. 99-106, 2007.

[60] P. Helsing, D. A. Nymoen, S. Ariansen et al., "Populationbased prevalence of CDKN2A and CDK4 mutations in patients with multiple primary melanomas," Genes Chromosomes and Cancer, vol. 47, no. 2, pp. 175-184, 2008.

[61] V. Bataille, "Genetic epidemiology of melanoma," European Journal of Cancer, vol. 39, no. 10, pp. 1341-1347, 2003.

[62] A. Liede, B. Y. Karlan, and S. A. Narod, "Cancer risks for male carriers of germline mutations in BRCA1 or BRCA2. A review of the literature," Journal of Clinical Oncology, vol. 22, no. 4, pp. 735-742, 2004.

[63] D. E. Freedberg, S. H. Rigas, J. Russak et al., "Frequent p16independent inactivation of p14ARF in human melanoma," Journal of the National Cancer Institute, vol. 100, no. 11, pp. 784-795, 2008.

[64] M. Singh, J. Lin, T. L. Hocker, and H. Tsao, "Genetics of melanoma tumorigenesis," The British Journal of Dermatology, vol. 158, no. 1, pp. 15-21, 2008.

[65] C. Dahl and P. Guldberg, "The genome and epigenome of malignant melanoma," APMIS, vol. 115, no. 10, pp. 1161-1176, 2007.

[66] A. J. Miller and M. C. Mihm Jr., "Melanoma," The New England Journal of Medicine, vol. 355, no. 1, pp. 51-65, 2006.

[67] H. Davies, G. R. Bignell, C. Cox et al., "Mutations of the BRAF gene in human cancer," Nature, vol. 417, no. 6892, pp. 949 954, 2002.

[68] D. Wu, M. Wang, X. Wang et al., "Lack of BRAF ${ }^{V 600 E}$ mutations in giant congenital melanocytic nevi in a chinese population," The American Journal of Dermatopathology, vol. 33, no. 4, pp. 341-344, 2011.

[69] J. L. Maldonado, J. Fridlyand, H. Patel et al., "Determinants of BRAF mutations in primary melanomas," Journal of the National Cancer Institute, vol. 97, pp. 401-402, 2003.

[70] N. M. Richmond-Sinclair, E. Lee, M. C. Cummings et al., "Histologic and epidemiologic correlates of P-MAPK, Brn-2, pRb, p53, and p16 immunostaining in cutaneous melanomas," Melanoma Research, vol. 18, no. 5, pp. 336-345, 2008.

[71] J. A. Curtin, K. Busam, D. Pinkel, and B. C. Bastian, "Somatic activation of KIT in distinct subtypes of melanoma," Journal of Clinical Oncology, vol. 24, no. 26, pp. 4340-4346, 2006.
[72] J. Lutzky, J. Bauer, and B. C. Bastian, "Dose-dependent, complete response to imatinib of a metastatic mucosal melanoma with a K642E KIT mutation," Pigment Cell and Melanoma Research, vol. 21, no. 4, pp. 492-493, 2008.

[73] G. Bollag, P. Hirth, J. Tsai et al., "Clinical efficacy of a RAF inhibitor needs broad target blockade in BRAF-mutant melanoma," Nature, vol. 467, no. 7315, pp. 596-599, 2010.

[74] K. T. Flaherty, I. Puzanov, K. B. Kim et al., "Inhibition of mutated, activated BRAF in metastatic melanoma," The New England Journal of Medicine, vol. 363, no. 9, pp. 809-819, 2010.

[75] J. N. Sondergaard, R. Nazarian, Q. Wang et al., "Differential sensitivity of melanoma cell lines with BRAF ${ }^{V 600 E}$ mutation to the specific Raf inhibitor PLX4032," Journal of Translational Medicine, vol. 8, article 39, 2010.

[76] A. Viros, J. Fridlyand, J. Bauer et al., "Improving melanoma classification by integrating genetic and morphologic features," PLoS Medicine, vol. 5, article e120, 2008.

[77] N. Ichii-Nakato, M. Takata, S. Takayanagi et al., "High frequency of BRAFV600E mutation in acquired nevi and small congenital nevi, but low frequency of mutation in mediumsized congenital nevi," Journal of Investigative Dermatology, vol. 126, no. 9, pp. 2111-2118, 2006.

[78] C. D. Van Raamsdonk, V. Bezrookove, G. Green et al., "Frequent somatic mutations of GNAQ in uveal melanoma and blue naevi," Nature, vol. 457, no. 7229, pp. 599-602, 2009. 


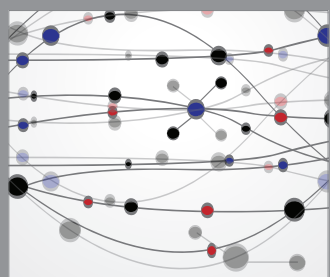

The Scientific World Journal
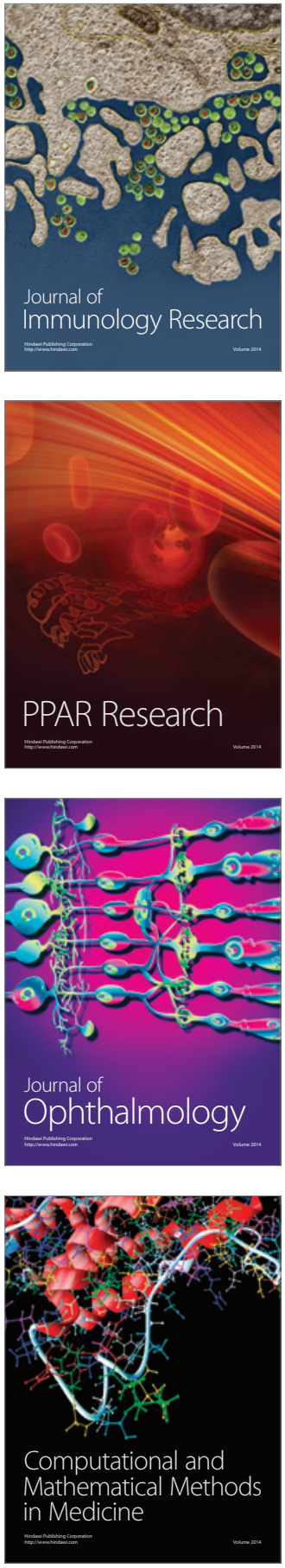

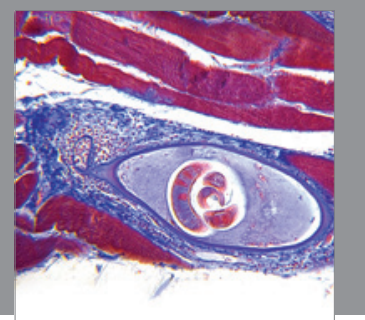

Gastroenterology

Research and Practice
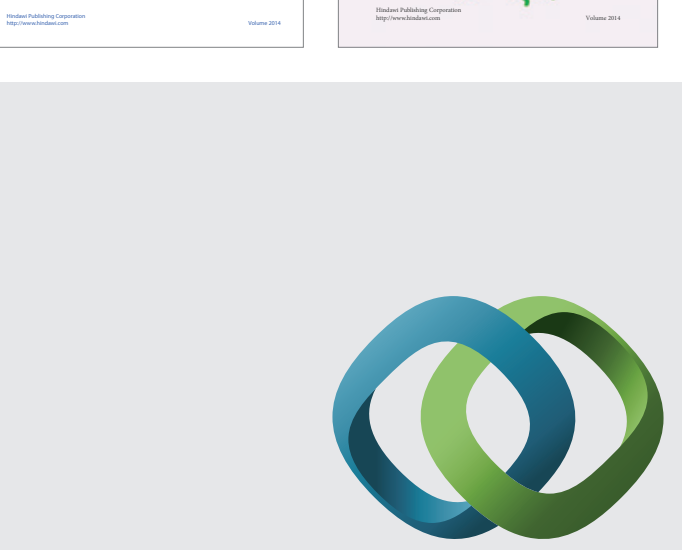

\section{Hindawi}

Submit your manuscripts at

http://www.hindawi.com
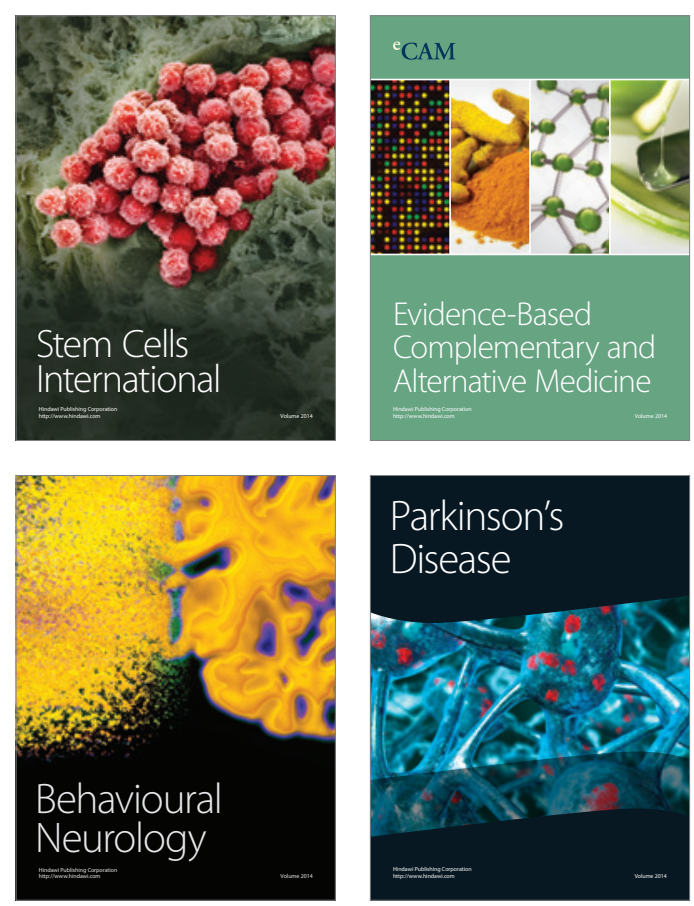

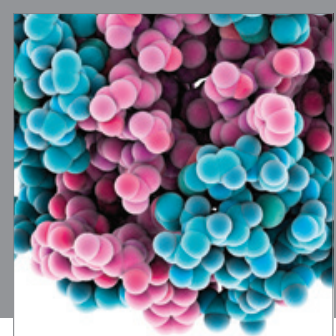

Journal of
Diabetes Research

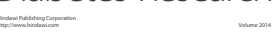

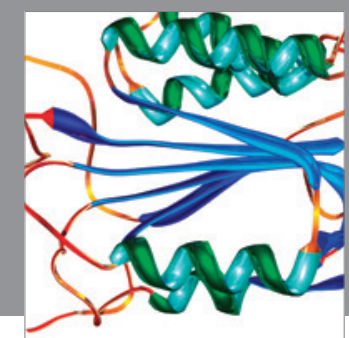

Disease Markers
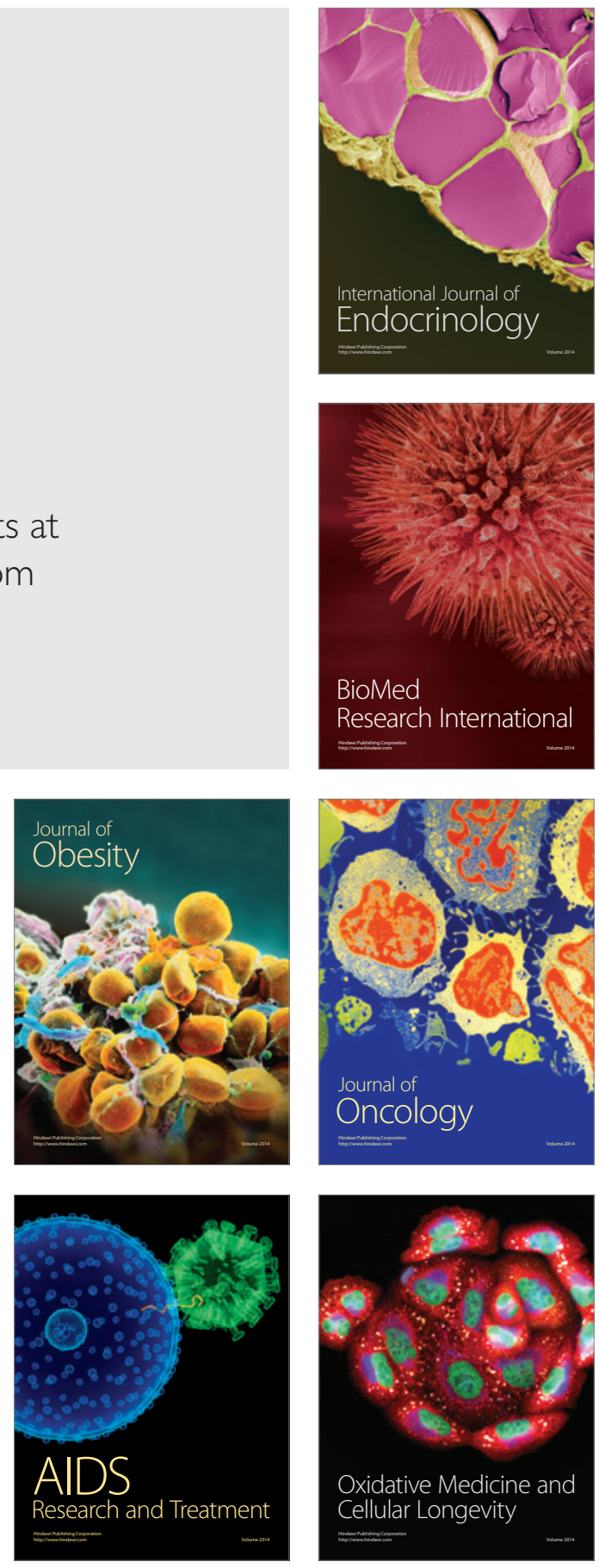